\title{
PENGEMBANGAN MODEL PEMBELAJARAN AKTIFITAS JASMANI UNTUK MEMBENTUK KARAKTER MELALUI KOLABORATIF PERMAINAN TRADISIONAL BAGI SISWA SEKOLAH DASAR
}

\author{
Rizky Anissa Putri \\ Program Studi Pendidikan Guru Sekolah Dasar \\ Universitas PGRI Semarang
}

Email: ririzkyanissa97@gmail.com

\begin{abstract}
ABSTRAK
Penelitian ini bertujuan untuk mengembangkan model pembelajaran yang berbasis aktifitas jasmani dalam karakter toleransi pada $\mathrm{k}$ melalui permainan tradisional. Penelitian ini juga bertujuan sebagai bahan ajar guru Sekolah Dasar pada mata pelajaran penjasorkes. Penelitian ini dilakukan untuk memperoleh informasi tentang : pengembangan dan penerapan model pembelajaran berbasis aktifitas jasmani dalam membentuk karakter siswa melalui permainan tradisional pada siswa Sekolah Dasar dan mengetahui efektifitas, efisiensi, serta daya tarik hasil pengembangan pembelajaran gerak dasar siswa. Jenis penelitian ini adalah penelitian pengembangan dengan menggunakan model pengembangan Research and Development (R\&D) dengan menggunakan permainan tradisional yang dimodifikasi. Instrumen yang digunakan dalam penelitian dan pengembangan ini angket pengembangan permainan tradisional untuk membentuk karakter siswa Sekolah Dasar. Berdasarkan dari hasil penelitian ini, menunjukkan bahwa hasilnya adalah $95 \%$ sangat cukup baik/bagus dengan melalui permainan tradisional yang dimodifikasi sehingga siswa lebih tertarik dalam mengikuti pembelajaran penjasorkes. Dengan begitu maka penerapan permainan tradisional yang dimodifikasi dapat digunakan dan dipraktekkan dalam pembelajaran mata pelajaran penjasorkes pada siswa Sekolah Dasar. Berdasarkan penilaian para ahli materi dan guru penjasorkes dapat disimpulkan bahwa pengembangan model permainan tradisional yang disusun sangat baik dan efektif, sehingga model permainan layak digunakan untuk pembelajaran pendidikan jasmani pada siswa Sekolah Dasar.
\end{abstract}

Keywords: Model Pembelajaran, Karakter Toleransi, Gerak Dasar, Permainan Tradisional

\begin{abstract}
This study aims to develop a learning model based on physical activity in the character of tolerance in $k$ through traditional games. This study also aims as teaching materials for elementary school teachers in Physical Education subjects. This research was conducted to obtain information about: the development and application of physical activity based learning models in shaping student character through traditional games on elementary school students and knowing the effectiveness, efficiency, and attractiveness of the results of the development of basic student learning. This type of research is development research using the Research and Development (R\&D) development model using modified traditional games. The instrument used in this research and development questionnaire was the development of traditional games to shape the character of elementary school students. Based on the results of this study, it shows that the result is $95 \%$ very good / good by going through a modified traditional game so that students are more interested in participating in physical education learning. That way the application of the modified traditional game can be used and practiced in the learning of Physical Education subjects in elementary school students. Based on the assessment of material experts and physical education teachers, it can be concluded that the development of traditional game models that are arranged very well and effectively, so that the game model is suitable for use in physical education learning in elementary school students.
\end{abstract}

Keywords: Model Pembelajaran, Karakter Toleransi, Gerak Dasar, Permainan Tradisional 


\section{PENDAHULUAN}

Pendidikan Jasmani, Olahraga dan Kesehatan di sekolah selain bertujuan untuk menjaga kestabilan kesegaran jasmani siswa juga berperan sebagai media penanaman nilai-nilai olahraga yang terkandung di dalamnya, seperti halnya kesopanan, kejujuran, kedisiplinan, sportivitas, tanggung jawab, pantang menyerah dan pola hidup sehat (Hadiyah \& Nurhayati, 2013:118). Dwiyogo (2010: 214) mengunakan istilah Pendidikan Jasmani yang dipakai dalam Pendidikan Jasmani, Olahraga dan Kesehatan di sekolah, bertujuan untuk mengembangkan fisik, mental, emosi, dan sosial. Dalam pendidikan jasmani untuk menerapkan pembelajaran dapat menggunakan sebuah permainan, termasuk permainan tradisional. Bermain merupakan kegiatan ataupun aktivitas wajib yang dilakukan anak-anak untuk mengenal lingkungan sekitar, bermain juga sering dilakukan orang dewasa untuk melepaskan kejenuhan dan menghilangkan stres. Bermain (play) adalah setiap kegiatan yang dilakukan untuk kesenangan yang ditimbulkannya, tanpa mempertimbangkan hasil akhir. Menurut Aqib dan Sujak (2011) "karakter berarti individu memiliki pengetahuan tentang potensi dirinya, yang ditandai dengan nilai-nilai seperti reflektif, percaya diri, rasional, logis, kritis, analitis, kreatif dan inovatif, mandiri, hidup sehat, bertanggung jawab, cinta ilmu, sabar, berhati-hati, rela berkorban, pemberani, dapat dipercaya, jujur, menepati janji, adil, rendah hati, malu berbuat salah, pemaaf, berhati lembut, setia, bekerja keras, tekun, ulet/gigih, teliti, berinisiatif, berfikir positif, disiplin, antisipatif, inisiatif, visoner, bersahaja, bersemangat, dinamis, hemat/efisien, menghargai waktu, pengabdian/dedikatif, pengendalian diri, produktif, ramah, cinta keindahan (estetis), sportif, tabah, terbuka dan tertib". Menurut Suharjana (2011, p. 4) bermain pada hakikatnya merupakan salah satu kebutuhan hidup bagi anak. Dalam kehidupan anak, bermain merupakan latihan-latihan yang dilakukan agar anak menjadi manusia dewasa yang lebih banyak mendapatkan kesempatan untuk melatih potensi-potensi yang ada pada dirinya, oleh karena itu bermain tidak dapat dipisahkan dari kehidupan anak itu sendiri. Menurut Linggar (2010, p. 1) olahraga/permainan tradisional adalah jenis olahraga yang timbul berdasarkan permainan dari masingmasing suku dan etnis di Indonesia. Menurut Undang-Undang Republik Indonesia Tentang Sistem Keolahragaan Nasional yakni terdapat pada BAB VI Pasal 17 tentang ruang lingkup olahraga yang meliputi olahraga pendidikan, olahraga rekreasi, dan olahraga prestasi. Permainan tradisional dapat mencangkup ketiga ruang lingkup olahraga tersebut. Permainan tradisional dapat dijadikan sebagai olahraga pendidikan karena permainan tradisional dapat mengembangkan aspek psikomotorik, aspek kognitif dan aspek afektif, sama halnya dengan pendidikan jasmani. Olahraga rekreasi, dengan bermain permainan tradisonal dan akibat ditimbulkanya seperti rasa senang, maka dapat dijadikan sebagai penawar dari rutinitas aktivitas belajar siswa, dengan harapan dapat meminimalis rasa jenuh/bosan pada siswa.

Kendala yang sering terjadi pada pembelajaran permainan tradisional adalah kurang kreatifnya guru dalam merancang permainan atau melakukan modifikasi permainan tradisional menjadi lebih mudah, menyenangkan, dan aman yang tidak menyebabkan siswa menjadi cepat bosan dan guru juga jarang memberikan permainan tradisional saat aktivitas pembelajaran, padahal dengan permainan tradisional salah satu cara membangun karaktera siswa. Guru di sini bertindak sebagai sumber belajar atau fasilitator dan siswa sebagai pebelajar atau orang yang belajar.

Dalam penelitian ini, maka peneliti bermaksud mengembangkan model pembelajaran berbasis aktivitas jasmani dengan hasil penelitian tentang penerapan 
permainan tradisional pada pembelajaran penjas. Model pembelajaran PJOK bagi para guru pengajar dan diterapkan pada proses pembelajaran PJOK untuk memperkenalkan pada siswa nilai-nilai budaya yang terkandung dalam permainan tradisional tersebut. Dimana terdapat pengaruh pemberian permainan tradisional terhadap efektivitas pembelajaran pendidikan jasmani, kesehatan dan olahraga pada siswa kelas SD ( Sekolah Dasar).

\section{METODE \\ Jenis Penelitian}

Metode dalam penelitian pengembangan permainan tradisional ini termasuk ke dalam penelitian dan pengembangan (Research and Development). Menurut Borg \& Gall (2007: 589) "research and development ( $R$ and $D$ ) is an insdustry-based development in which the findings of research are used to design new products and prosedures, which then are systematically field-tested, evaluate, and refined until they meet specified criteria of effectivness, quality, or similar standards".

\section{Populasi}

Penelitian ini menggunakan subyek siswa Sekolah Dasar yang ada di SD N
Sendangmulyo 01 yang terdiri dari siswa 65 kelas III, IV, dan V.

Teknik Pengumpulan Data

Menggunakan kuisioner dengan skala Likert. Data dianalisis dengan menggunakan uji - t beda mean.

\section{Analisa Data}

Penelitian ini merupakan evaluasi reflektif yang dilakukan dengan membandingkan pendidikan karakter dari berbagai kurun waktu yang diperoleh peserta didik melalui permainan tradisional.

\section{HASIL DAN PEMBAHASAN}

Hasil analisis data tes awal variabel karakter sebelum diberikan perlakuan dengan permainan kolaboratif, yang dilakukan terhadap 65 orang siswa, diperoleh skor tertinggi 168, skor terendah 91 , jarak pengukuran yaitu 77 , skor ratarata 139,55 , median 130 dan simpangan baku 14,45. Sedangkan dari hasil analisis data tes akhir setelah diberikan perlakuan ditemukan skor tertinggi 267, skor terendah 141, skor rata-rata 207,51, jarak pengukuran 126, median 204, dan simpangan baku 25,43. Untuk lebih jelasnya hasil data pengaruh dari permainan kolaboratif terhadap optimalisasi pembentukan karakter tersebut dapat dilihat tabel 1.

Tabel 1. Distribusi Frekuensi Hasil Data Tes Awal dan Tes Akhir

\begin{tabular}{|c|c|c|c|c|c|}
\hline \multirow[b]{2}{*}{$\begin{array}{l}\text { Kelas } \\
\text { Interva } \\
\text { I }\end{array}$} & \multirow[b]{2}{*}{ Kategori } & \multicolumn{2}{|c|}{ Tes Awa } & \multicolumn{2}{|c|}{ Tes Akhir } \\
\hline & & $\begin{array}{c}\text { Frekuens } \\
\text { i } \\
\text { absolut }\end{array}$ & $\begin{array}{c}\text { Frekuen } \\
\text { si } \\
\text { relatif }\end{array}$ & $\begin{array}{c}\text { Frekuens } \\
\text { i } \\
\text { absolut }\end{array}$ & $\begin{array}{c}\text { Frekuens } \\
\text { i } \\
\text { relatif }\end{array}$ \\
\hline$\square 235$ & Baik Sekali & 0 & 0 & 4 & 6,15 \\
\hline $\begin{array}{c}195- \\
235\end{array}$ & Baik & 0 & 0 & 48 & 73,85 \\
\hline $\begin{array}{c}155- \\
194\end{array}$ & Sedang & 11 & 16,92 & 12 & 18,46 \\
\hline $\begin{array}{c}115- \\
154\end{array}$ & Kurang & 52 & 80 & 1 & 1,54 \\
\hline$\square 115$ & $\begin{array}{c}\text { Kurang } \\
\text { Sekali }\end{array}$ & 2 & 3,08 & 0 & 0 \\
\hline Jumlah & & 65 & 100 & 65 & 100 \\
\hline
\end{tabular}

Dari hasil data tes awal yang dideskripsikan pada tabel di atas maka jelaslah bahwa, siswa yang berada dalam kategori baik sekali dan baik tidak ada 
satu orangpun yang memilikinya. Selanjutnya untuk kategori sedang yaitu 11 orang $(16,92 \%)$, kategori kurang yaitu sebanyak 52 orang $(80 \%)$ dan kategori kurang sekali yaitu ada 2 orang $(3,08 \%)$. Sedangkan untuk variabel karakter pada tes akhir ditemukan bahwa siswa yang berada pada kategori baik sekali yaitu ada
4 orang $(6,15 \%)$, kategori baik yaitu sebanyak 48 orang $(73,85 \%)$ dan kategori sedang yaitu 12 orang $(18,46 \%)$. Selanjutnya untuk kategori kurang yaitu hanya 1 orang $(1,54 \%)$ dan kategori kurang sekali tidak ada satu orangpun yang memilikinya. Untuk lebih jelasnya dapat dilihat pada grafik berikut ini.

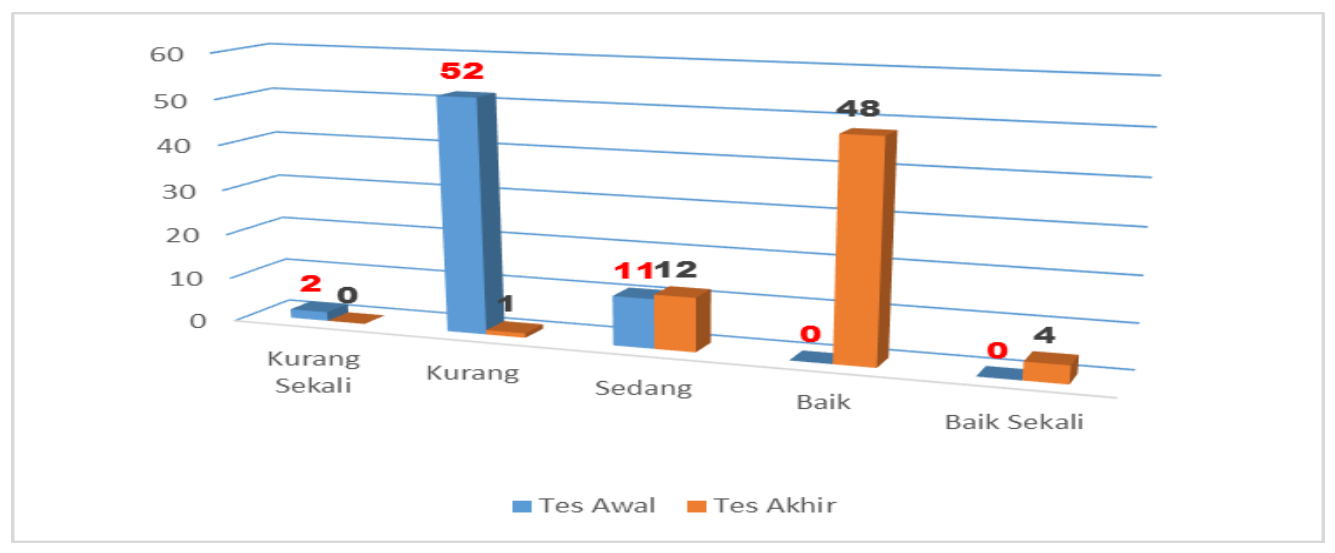

\section{Gambar 1. Grafik Tes Awal dan Akhir Data Karakter}

Berdasarkan deskripsi data yang dikemukakan sebelumnya, maka data tes awal siswa untuk karakter yang berada di bawah kelompok rata-rata yaitu sebanyak 32 orang $(49,23 \%)$, dalam kelompok ratarata ada 2 orang $(3,08 \%)$ dan di atas kelompok rata-rata yaitu ada 31 orang $(47,69 \%)$. Sedangkan untuk data tes akhir yang berada di bawah kelompok rata-rata yaitu 28 orang $(43,08 \%)$, dalam kelompok rata-rata tidak ada satu orangpun siswa yang memilikinya. Sedangkan untuk di atas kelompok rata-rata yaitu sebanyak 37 orang $(56,92 \%)$. Selanjutnya untuk uji persyaratan analisis yang digunakan dalam penelitian ini yaitu dengan uji normalitas data untuk mengetahui apakah data dari variabel yang diteliti berdistribusi normal atau tidak dengan menggunakan uji Lilliefors dengan taraf signifikansi $\square>$ 0,05 . Hipotesis uji Lilliefors. Uji normalitas tes awal ditemukan $L_{\text {observasi }} 0,044<L_{\text {tabel }}$ 0,110 dan tes akhir ditemukan $L_{\text {observasi }}$ $0,109<L_{\text {tabel }} 0,110$. Artinya variabel yang diteliti berasal dari data yang berdistribusi normal. Setelah uji persyaratan analisis dilakukan dan ternyata semua data variabel penelitiain memenuhi persyaratan untuk dilakukan pengujian statistik lebih lanjut yaitu pengujian hipotesis. Hasil pengujian hipotesis penelitian yaitu: terdapat pengaruh yang signifikan pengembangan permainan kolaboratif dalam pendidikan jasmani dan olahraga di Sekolah Dasar Sendangmulyo 01 untuk optimalisasi pembentukan karakter. Uji statistik yang digunakan adalah t-test yaitu melihat pengaruh dari rata-rata hitung dalam satu kelompok yang sama dengan taraf signifikan 0,05 ditemukan $t_{\text {hitung }}=$ $34,62>t_{\text {tabel }}=1,99$. Dengan demikian dapat disimpulkan bahwa permainan kolaboratif dalam pendidikan jasmani dan olahraga di sekolah dasar memberikan pengaruh yang signifikan terhadap optimalisasi pembentukan karakter dengan peningkatan nilai rata-rata sebesar 70,28 yaitu dari skor rata-rata tes awal 139,55 dan tes akhir menjadi 209,83.

\section{KESIMPULAN}

Berdasarkan hasil penelitian yang 
dikemukan sebelumnya, maka dapat disimpulkan bahwa terdapat pengaruh pengembangan permainan kolaboratif dalam pendidikan jasmani dan olahraga di Sekolah Dasar Sendangmulyo 01 untuk optimalisasi pembentukan karakter dengan ditemukan thitung $=34,62$

$>t_{\text {tabel }}=1,99$ pada taraf signifikan 0,05. Artinya apabila siswa lebih banyak diberikan permainan kolaboratif dengan mengaitkan indikator yang terdapat dalam permainan dengan indikator karakter tersebut maka akan dapat menghasilkan siswa yang memiliki karakter yang lebih baik.

\section{DAFTAR PUSTAKA}

Aqib Zainal \& Sujak. 2011. Panduan \& Aplikasi Pendidikan Karakter. Bandung: Yrama Widya

Dwiyogo, W. 2010. Dimensi Teknologi Pembelajaran Pendidikan Jasmanai Dan Olahraga. Jakarta: Wineka Media.

Hadiyah, \& Nurhayati. 2013. Survei Tentang Sikap Siswa Dalam Pembelajaran Pendidikan Jasmani Olahraga Dan Kesehatan. Jurnal Pendidikan Olahraga dan Kesehatan, 01 (01): 118.(Online), diakses pada 20 april 2017.

Linggar, S. (2010). Ayo lestarikan permainan tradisional. Jakarta: CV Karya Mandiri Nusantara.

Suharjana, F. (2011). Pengembangan pembelajaran senam melalui bermain di sekolah dasar. Jurnal Pendidikan Jasmani Indonesia, 8(1). Retrieved from https://journal.uny.ac.id/index.php/ipii larticle/view/3479 